\title{
Antibacterial activity of extracted phycocyanin from Oscillatoria sp.
}

\author{
Abirami Shanmugam ${ }^{1}$, Santhosh Sigamani ${ }^{2}$, Hemalatha Venkatachalam ${ }^{1}$, Jamuna Devi Jayaraman ${ }^{1}$, \\ Dhandapani Ramamurthy ${ }^{1^{*}}$ \\ ${ }^{1}$ Fermentation technology Laboratory, Department of Microbiology, Periyar University, Salem-636011, Tamilnadu, India. \\ ${ }^{2}$ Applied Microbiology Laboratory, Department of Microbiology, Periyar University, Salem-636011, Tamilnadu, India.
}

\begin{tabular}{|c|c|}
\hline ARTICLE INFO & ABSTRACT \\
\hline Article history: & \multirow{8}{*}{$\begin{array}{l}\text { The intention of the proposed work is to study on extraction of phycocyanin pigment from blue green algae and } \\
\text { its antibacterial activity. The water sample was collected from Mettur dam and brought to the laboratory for } \\
\text { isolation and microscopic analysis. The isolated colony was found to be Oscillatoria sp. and it was grown in BG } \\
11 \text { medium. The Oscillatoria sp. was grown in } 1000 \mathrm{~mL} \text { and centrifuged for biomass. Then the centrifuged } \\
\text { biomass was weighed and used for extraction of phycocyanin. On analysis of the phycocyanin from Oscillatoria } \\
s p \text {. it was found that the phycocyanin concentration was } 2.39 \mathrm{mg} / \mathrm{mL} \text { and Extraction yield was obtained to be } \\
4.735 \mathrm{mg} / \mathrm{g} \text {. The protein estimation of the phycocyanin pigment using Lowry's method was found to be } 273.8 \\
\mu \mathrm{g} / \mathrm{mL} \text {. Phycocyanin pigment was used to identify the antimicrobial activity against three pathogenic bacteria. } \\
\text { Finally the antimicrobial activity was carried out on Muller hintonQ agar plates with different concentrations of } \\
\text { phycocyanin such as } 20 \mu \mathrm{L}(4.48 \mu \mathrm{g}), 40 \mu \mathrm{L}(13.44 \mu \mathrm{g}) \text { and } 60 \mu \mathrm{L}(17.92 \mu \mathrm{g}) \text {. The obtained results shows the } \\
\text { ability of phycocyanin as antimicrobial agent against human pathogens. }\end{array}$} \\
\hline Received on: & \\
\hline Accepted on: 1 & \\
\hline Available online: $30 / 03 / 2017$ & \\
\hline Key words: & \\
\hline Oscillatoria sp., & \\
\hline & \\
\hline & \\
\hline
\end{tabular}

\section{INTRODUCTION}

Microalgae and cyanobacteria are photosynthetic microorganisms that can be used in a wide variety of applications. These microorganisms can be effectively used in $\mathrm{CO}_{2}$ capture from the atmosphere or from flue gas emissions and can remove nutrients from wastewaters, playing an important role in wastewater treatment processes (Razzak et al., 2013). Nitrogen removal efficiencies between 80 and $90 \%$ and phosphorus removal efficiencies close to $100 \%$ have already been reported (Zhu et al., 2013). Cyanobacteria, also known as blue green algae (BGA) are considered to be the oldest form of life on the earth. They possess a wide range of coloured components, including carotenoids, chlorophyll and phycobiliproteins. Phycobiliproteins (PBPs) are large water

\footnotetext{
* Corresponding Author

Dhandapani Ramamurthy, Fermentaiton Technology Laboratory, Department of Microbiology, Periyar University, Salem-636011, India. Email:danpani@gmail.com
}

soluble supra molecular protein aggregates involved in light harvesting in these organisms and may comprise as much as 40$60 \%$ of the total soluble protein in these cells (Bogorad, 1975). Cyanobacteria with high levels of specific phycobiliproteins are of commercial interest. One common pigment is phycocyanin, which is a blue color. Phycocyanin is used as colorant in food (chewing gums, dairy products, gellies etc.) and cosmetics such as lipstick and eye liners in Japan, Thailand and China. It has also shown to have therapeutic value (immuno-modulating activity and anticancer activity) (Lijima et al., 1982).

The extraction solution most frequently used for extraction is a phosphate buffer in a relatively large concentration (0.001 M to $0.05 \mathrm{M}$ ) (Furuki et al., 2003), but in some case $90 \%$ acetone (Zimba, 2012) or lyzozyme (Boussiba and Richmond, 1979) is also suitable for cell wall rupturing. In these studies, the extraction protocols were followed by spectrophotometric (Sarada et al., 1999), liquid chromatographic, capillary (Viskari and Colyer, 2003) and gel electrophoresis (Soni et al., 2006) or single step chromatographic analyses. 
Most studies have dealt with species originating from tropical/subtropical freshwater alkaline lakes (Spirulina platensis, Silveira et al., 2007, Furuki et al., 2003), salt water bodies (Oscillatoria qudripunctulata, Soni et al., 2006) or marine environments (Synechococcus sp., 6301 Yamanaka and Glazer, 1980; Lyngbya sp., Patel et al., 2005). The marine cyanobacterial group is well documented for their bioactive compounds possessing antimicrobial properties, while there are only few reports available with fresh water cyanobacteria. In this work, we report the antibacterial activity of the C-phycocyanin extracted from Oscillatoria sp. isolated from fresh water.

\section{MATERIALS AND METHODS}

\section{Sample collection and processing}

The water sample was collected from the Mettur dam in $15 \mathrm{~mL}$ centrifuge tubes and brought to laboratory. The water sample was serially diluted and the single colonies were picked and inoculated in $1 \mathrm{~mL}$ of BG11 Medium.

\section{BG 11 media For Growth}

The isolated colonies of Microalgae grown in $1 \mathrm{~mL}$ of media were then transferred to $4 \mathrm{~mL}$ media followed by scaling up of media to $1000 \mathrm{~mL}$ medium. After the growth was completely observed it was taken for further study.

\section{Morphology and Identification}

The morphology of the microalgae was observed using Microscope at different magnification i.e. $10 \mathrm{X}$ and $40 \mathrm{X}$. The culture was observed for its morphology and its structure.

\section{Extraction of phycocyanin \\ 1 M Tris-HCl Stock Solution Preparation}

Phycocyanin was extracted from the fresh cyanobacterial strain biomass using the modified methods of Sarada et al. (1999). Thirty-four day grown cyanobacterial cells were harvested by centrifugation at $3000 \mathrm{x} \mathrm{g}$ for $5 \mathrm{~min}$ at $20^{\circ} \mathrm{C}$. Cell pellets were washed with $1 \mathrm{M}$ Tris- $\mathrm{HCl}$ buffer $(\mathrm{pH} 8.1)$. One volume of washed cell mass was re-suspended in five volumes of the same buffer and treated for the extraction of phycocyanin by physically (freezing-thawing method).

\section{Physical extraction}

The experiment was carried out to examine the effect of physical (freezing-thawing) method of phycocyanin produced by the cyanobacterial strain. In the physical approach, the wet biomass was frozen at $-20^{\circ} \mathrm{C}$ (for at least 4 hours) then thawed at each $25^{\circ} \mathrm{C}$ in four cycles. In all the treatments, the cell debris were removed by centrifugation at $10,000 \mathrm{X} \mathrm{g}$ and the supernatant was pooled and labeled as crude extract.

\section{Partial purification}

The partial purification of the extracted phycocyanin pigment was carried out using ammonium sulphate precipitation for overnight at $4{ }^{\circ} \mathrm{C}$ on magnetic stirrer. After the Ammonium sulphate precipitation the pigment is centrifuged and taken for further studies.

\section{Phycocyanin yield}

The phycoyanin yield and extraction yield of phycocyanin is calculated by the following formulae (Bennett and Bogorad, 1973):

CPC

$$
=\frac{\left(\mathrm{OD}_{620}-0.474 \times \mathrm{OD}_{650}\right)}{5.34}
$$

Extraction Yield $=\frac{\mathrm{CPC}(\mathrm{V})}{\mathrm{DB}}$

where, $\mathrm{V}$ is the solvent volume $(\mathrm{mL})$ and $\mathrm{DB}$ is dry biomass $(\mathrm{g})$.

\section{Protein Estimation}

Protein was estimated by the method of Lowry et al. (1951) using Bovine serum albumin asstandard.

\section{Collection of clinical specimens}

The three clinical pathogens were obtained from Fermentation Technology Laboratory. Bacterial pathogens obtained were Pseudomonas sp., Klebsiella sp. and Staphylococcus aureus.

\section{Maintenance of clinical pathogens}

The samples were streaked on Blood agar, Nutrient agar and Mac-conkey agar and incubated at $37^{\circ} \mathrm{C}$ for 24 hours. The plates were observed after 24 hours of incubation to identify the types and number of colonies.

\section{Examination of clinical pathogens}

The examination of the pathogens was done using Microscopic examination and Biochemical tests to confirm the bacterial isolates.

\section{Antimicrobial activity}

The antimicrobial activity of the partially purified phycocyanin was carried out using Disc diffusion method against the three clinical pathogens and the results were observed and tabulated.

\section{RESULTS}

\section{Sample Collection and Identification}

The water sample was collected from Mettur dam in 15 $\mathrm{mL}$ centrifuge tubes and brought to the laboratory. The water sample was serially diluted and the single colonies were picked and inoculated in $1 \mathrm{~mL}$ of BG11 Agar. The identification were made using microscopic observation under light microscope. They show long filaments of cells which can break into fragments called hormogonia when were seen under $40 \mathrm{X}$ observation (Fig. 1). 
a)

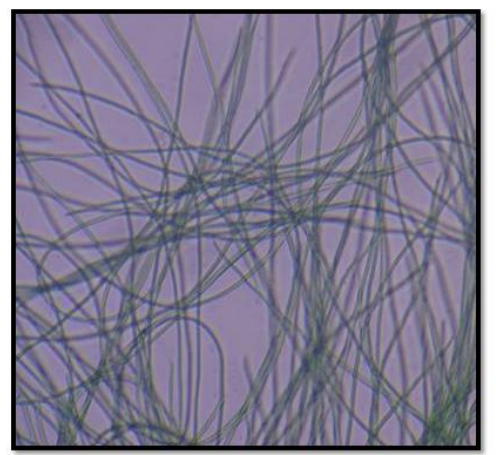

b)

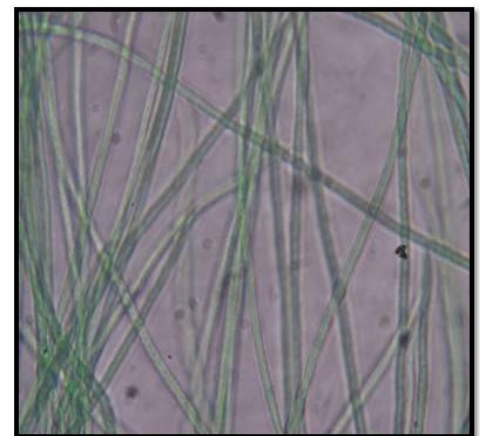

Fig. 1: Microscopic identification of Oscillatoria sp. In light microscope a) 10 $\mathrm{X}$ image, b)40 X image

\section{Cultivation of Microalgae}

The obtained strain was cultivated in $1000 \mathrm{~mL}$ of Erlenmeyer's Flask and it was kept in $16 \mathrm{hrs}$ light and $8 \mathrm{hrs}$ dark cycle. The growth was observed for three weeks and the OD value was checked using UV Spectrophotometer. The Maximum growth is attained when the OD value is more than 1 (Fig. 2).

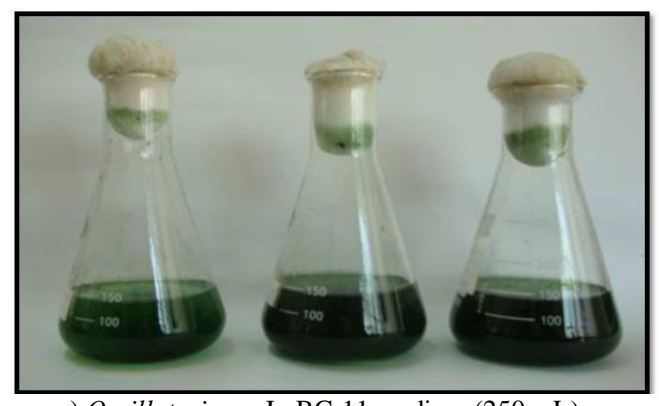

a) Oscillatoria sp. In BG 11 medium $(250 \mathrm{~mL})$

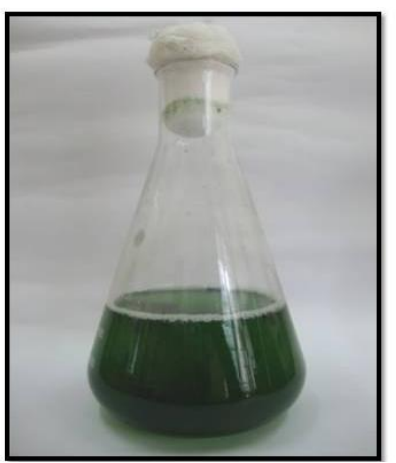

b) Oscillatoria sp. In BG 11 medium $(1000 \mathrm{~mL})$ Fig. 2: Cultivation of cyanobcteria in BG 11 medium.

\section{Biomass production}

The Oscillatoria $s p$. grown in $1000 \mathrm{~mL}$ was centrifuged for biomass. Finally the centrifuged biomass was weight and used for extraction of phycocyanin (Table 1). The Fresh weight and dry weight of the Biomass was calculated (Fig.3a).

Table 1: Amount of Biomass recovered after 1 month

\begin{tabular}{cccc}
\hline S.NO & $\begin{array}{c}\text { Name of the } \\
\text { organism }\end{array}$ & $\begin{array}{c}\text { Weight of } \\
\text { biomass } / \mathbf{~ m L}\end{array}$ & $\begin{array}{c}\text { Wet } \\
\text { dry Biomass }\end{array}$ \\
\hline 1. & Oscillatoria $\mathrm{sp}$. & $3.55 \mathrm{~g}$ & $1.2 \mathrm{gms}$ \\
\hline
\end{tabular}

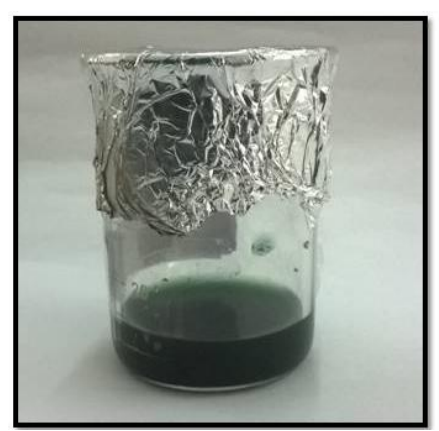

Fig. 3: a) Wet biomass of the Oscillatoria sp.

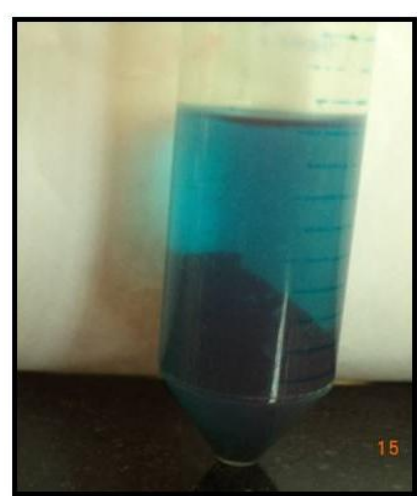

Fig. 3: b) Extracted phycocyanin pigment by freeze-thaw method.

\section{Extraction of Phycocyanin Pigment}

The Freeze thawed Biomass was centrifuged at $6000 \mathrm{rpm}$ for 10 mins and the supernatant was taken for further studies (Fig.3.b). The C- phycocyanin concentration (CPC) in $\mathrm{mg}^{-\mathrm{mL}^{-1}}$ was calculated from the optical densities at 650 and $620 \mathrm{~nm}$. On analysis of the phycocyanin from Oscillatoria $s p$. it was found that the Phycocyanin concentration was found to be $2.39 \mathrm{mg} / \mathrm{mL}$ (Table.2)

Table 2 : Phycocyanin yield obtained from Oscillatoria $s p$.

\begin{tabular}{cccc}
\hline S.No & Processed Phycocyanin & $\begin{array}{c}\text { C-phycocyanin } \\
\text { concentration } \\
\left(\mathbf{~ m g . m L}^{-1}\right)\end{array}$ & $\begin{array}{c}\text { Extraction } \\
\text { Yield } \\
\left(\mathbf{m g . g}^{-1}\right)\end{array}$ \\
\hline 1. & Crude phycocyanin & 1.21 & 3.51 \\
\hline 2. & $\begin{array}{c}\text { Ammonium sulphate } \\
\text { precipitation }\end{array}$ & 2.39 & 4.37 \\
\hline
\end{tabular}




\section{Partial purification}

Partially purified pigment is centrifuged and its supernatant is taken as partially purified pigment. This phycocyanin is then processed for further studies. (Figure.7)
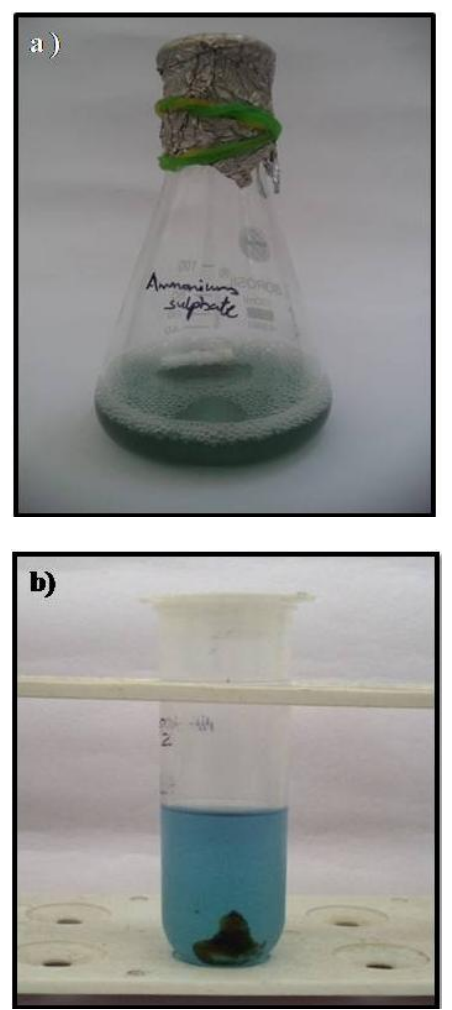

Fig. 7: Partial purification of phycocyanin pigment using ammonium per sulphate precipitation

a) Before centrifugation b) After centrifugation

\section{Protein Estimation and Determination}

Using lowry's method the protein was extracted and determined. The colour changes absorbance was read at $660 \mathrm{~nm}$. Bovine serum albumin (BSA) was used as a standard and the $\mathrm{R}^{2}$ value obtained was 0.995 . The values were plotted and the sample value was identified (Table 3).

Table 3: Estimation of protein in Oscillatoria sp.

\begin{tabular}{ccc}
\hline S.NO & OD value at $660 \mathrm{~nm}$ & Amount of protein present in sample \\
\hline 1. & 0.64 & $278.3 \mu \mathrm{g} / \mathrm{mL}$ \\
\hline
\end{tabular}

\section{Collection of Bacterial Colonies}

Pathogenic bacteria were obtained from Fermentation Technology Laboratory, Department of Microbiology, Periyar University, Salem.

\section{Examination of Bacterial Isolates}

Only three predominant individual colonies were selected and identified on the basis of colony morphological characteristics, Gram staining and biochemical characteristics ( Table 4.)
Table 4: Morphological characteristics of the Bacterial Isolates.

\begin{tabular}{ccccc}
\hline Bacterial & \multicolumn{4}{c}{ Microscopic examination } \\
\cline { 2 - 5 } isolates & Gram staining & $\begin{array}{c}\text { Spore } \\
\text { staining }\end{array}$ & $\begin{array}{c}\text { Motility } \\
\text { test }\end{array}$ & $\begin{array}{c}\text { Capsule } \\
\text { Staining }\end{array}$ \\
\hline S1 & $\begin{array}{c}\text { Gram Negative, } \\
\text { Rod }\end{array}$ & $\begin{array}{c}\text { Non spore } \\
\text { forming }\end{array}$ & Motile & $\begin{array}{c}\text { Non } \\
\text { capsulated }\end{array}$ \\
\hline S2 & $\begin{array}{c}\text { Gram negative, } \\
\text { Rod }\end{array}$ & $\begin{array}{c}\text { Non-spore } \\
\text { forming }\end{array}$ & $\begin{array}{c}\text { Non- } \\
\text { motile }\end{array}$ & Capsulated \\
\hline S3 & $\begin{array}{c}\text { Gram positive, } \\
\text { Cocci }\end{array}$ & $\begin{array}{c}\text { Non spore } \\
\text { forming }\end{array}$ & $\begin{array}{c}\text { Non- } \\
\text { motile }\end{array}$ & - \\
\hline
\end{tabular}

\section{Microscopic Examination}

All the three selected bacterial colonies were examined under microscope after Gram staining, capsule staining, spore staining and motility test. The results were observed and recorded (Fig.4).

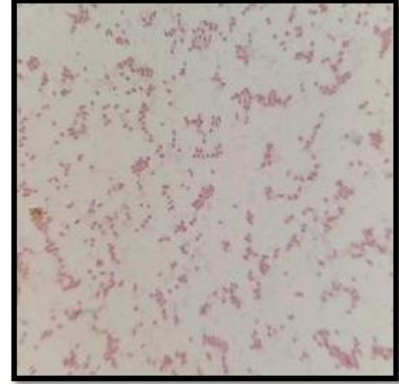

a) Klebsiella pneumonuae

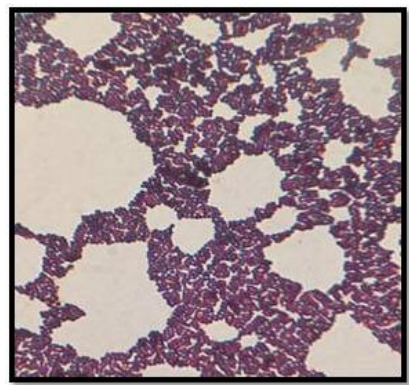

c) Staphylococcus aureus

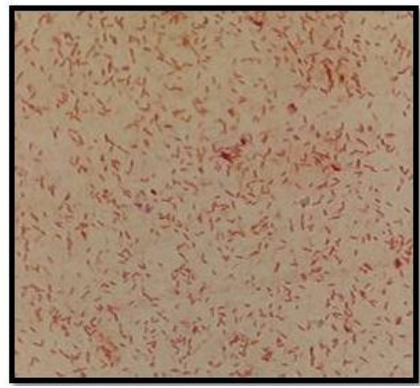

b)Pseudomonas aeruginosa

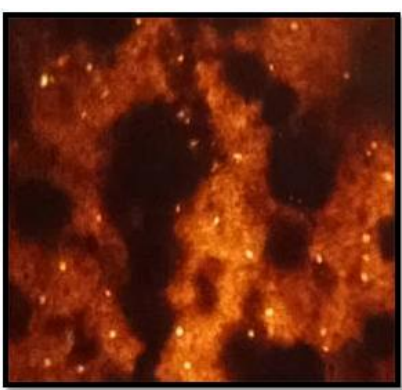

d) Capsule staining for
Fig. 4: Microscopic identification of clinical isolates gram staining (a, b, c,) Capsule staining (d).

\section{Biochemical analysis of isolated bacterial strains}

All the selected three bacterial isolates were characterized by the following biochemical analysis: Indole test, Methyl red test, Voges proskauer test, Citrate test, catalase test, oxidase test, Triple sugar iron test, Urease test, Carbohydrate fermentation test. Biochemical analysis results were observed and recorded (Table.5) (Fig.5).

Table 5: Biochemical characteristics of the Isolated Bacterial colonies.

\begin{tabular}{|c|c|c|c|c|c|c|c|c|c|}
\hline 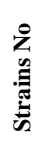 & 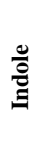 & 学 & 5 & 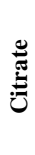 & $\overline{2}$ & 若 & 营 & 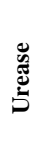 & 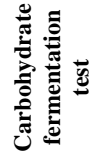 \\
\hline S1 & - & - & + & + & $\mathrm{G}+, \mathrm{H}_{2} \mathrm{~S}-$ & + & + & - & - \\
\hline S2 & - & - & + & + & $\mathrm{A}+, \mathrm{H}_{2} \mathrm{~S}-$ & _ & + & + & + \\
\hline S3 & 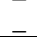 & $\bar{t}$ & _ & + & $\mathrm{G}+, \mathrm{H}_{2} \mathrm{~S}-$ & + & + & _ & + \\
\hline
\end{tabular}




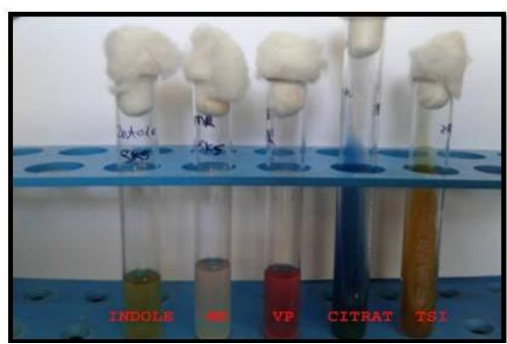

Klebsiella pneumonia

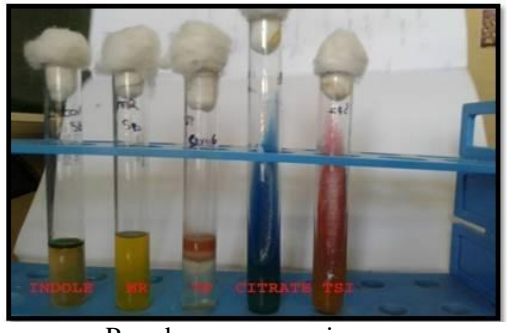

Pseudomonas aeruginosa

Fig. 5: Biochemical characteristics of clinical isolates.

\section{Antimicrobial activity}

Crude extract of Oscillatoria $s p$. showed maximum antibacterial activity against gram positive bacterial pathogens compared with Streptomycin. The phycocyanin pigment showed high activity against Klebsiella sp. compared to Streptomycin The phycocyanin pigment showed high activity against Klebsiella $s p$. compared to the other two pathogens (Table 6) (Figure 8).

Table 6: Antibacterial activity of extracted phycocyanin by Disc diffusion method

\begin{tabular}{ccccc}
\hline \multirow{2}{*}{ Pathogen } & \multicolumn{4}{c}{ Zone of inhibition } \\
\cline { 2 - 5 } & $\begin{array}{c}\mathbf{2 0} \\
\boldsymbol{\mu L}\end{array}$ & $\mathbf{4 0} \boldsymbol{\mu \mathbf { L }}$ & $\mathbf{6 0} \boldsymbol{\mu L}$ & \multirow{2}{*}{ Streptomycin } \\
\hline Pseudomonas aeruginosa & $5 \mathrm{~mm}$ & $8 \mathrm{~mm}$ & $9 \mathrm{~mm}$ & - \\
Klebsiella sp & $10 \mathrm{~mm}$ & $12 \mathrm{~mm}$ & $13 \mathrm{~mm}$ & $6 \mathrm{~mm}$ \\
Staphylococcus aureus & - & - & $1 \mathrm{~mm}$ & $11 \mathrm{~mm}$ \\
\hline
\end{tabular}

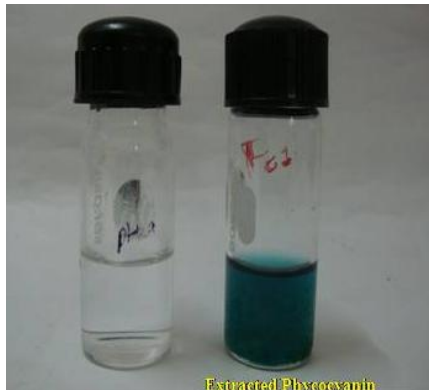

a) crude phycoyanin extracted from Oscillatoria sp.



Fig. 6: Extracted phyocaynin from Oscillatoria $s p$.

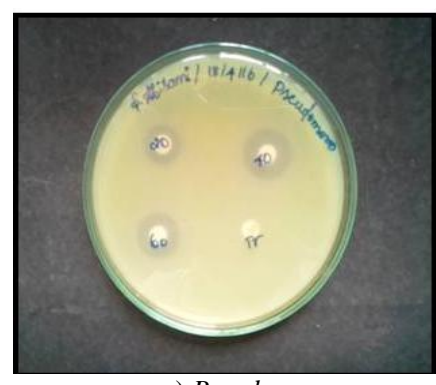

a) Pseudomonas sp.

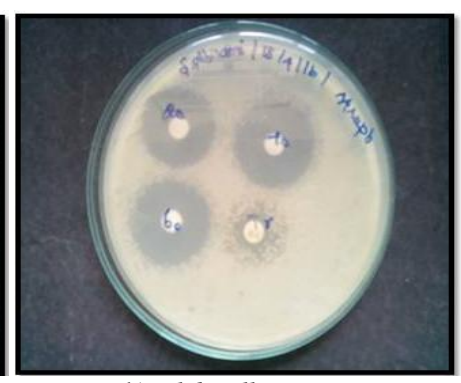

b) Klebsiella sp.

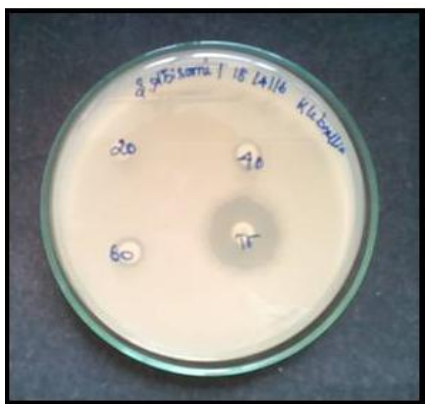

c) Staphylococcus aureus.

Fig. 8: Antibacterial activity of the extracted phycocyanin against three human pathosgens.

\section{DISCUSSION}

Rippika et al., (1979) isolated Anabaena constricta and Oscillatoria curviceps from paddy fields of Cuddalore District. The filamentous cyanobacterium Anabaena constricta and Oscillatoria curviceps were grown in culture tube at $30^{\circ} \mathrm{C} \pm 2{ }^{\circ} \mathrm{C}$ in the nitrogen-free $\mathrm{BG}-11$ liquid and nitrogen medium respectively and $\mathrm{pH}$ was adjusted to 7.9. Anabaena sp. was grown in BG-11 medium without nitrogen source and Oscillatoria $s p$. was cultured in BG-11 medium with nitrogen source. These cultures were maintained in laboratory conditions in daylight fluorescent tubes for $16 \mathrm{hrs}$ a day for 10 days. The cultured cyanobacterial species were used for further study.

Similarly, Bennett and Bogorod., (1973) took one volume of biomass and then resuspended in five times the volume of the same buffer followed by repeated freezing $\left(-20^{\circ} \mathrm{C}\right)$ and thawing $\left(4^{\circ} \mathrm{C}\right)$ shocks for the release of phycobiliproteins. The above procedure was continued till coloured supernatant was obtained from the biomass. The cell debris was removed by centrifugation at $12,000 \mathrm{rpm}$ for $10 \mathrm{~min}$. The absorbance of phycobiliprotein containing cell-free supernatants obtained by the centrifugation was measured at $562 \mathrm{~nm}, 615 \mathrm{~nm}$ and $652 \mathrm{~nm}$ using phosphate buffer as a blank. These wavelengths correspond to the absorption maxima of phycoerythrin (PE), phycocyanin (PC) and allophycocyanin (APC) respectively and was determined in spectrophotometer (Shimadzu, UV-1800, Japan). Showed that crude extract was subjected to a single step precipitation using 65 $\% \quad\left(\mathrm{NH}_{4}\right)_{2} \mathrm{SO}_{4}$ (Bio Xtra, [99 \%; Sigma-Aldrich) and kept overnight at $4{ }^{\circ} \mathrm{C}$. The pellet was recovered by centrifugation at $27,000 \mathrm{rpm}$ for $15 \mathrm{~min}$ at $4{ }^{\circ} \mathrm{Cand}$ dissolved in $10 \mathrm{~mL}$ of the same extraction buffer and termed as ammonium sulfate extract (ASE). 
$10 \mathrm{~mL}$ of ASE was dialyzed against the extraction buffer using dialyses membrane (Dialyses membrane-70, MWCO; 12-14 kD) procured from Hi-Media. Dialyses was performed twice against $1,000 \mathrm{~mL}$ extraction buffer, first at room temperature and again dialysed against $1,000 \mathrm{~mL}$ of extraction buffer at overnight. The resultant extract was recovered from the dialyses membrane and filtered through $0.45 \mathrm{~mL}$ filter.

The antibacterial activity of $S$. Maxima extracts were assayed against five bacterial strains ( $P$. aeruginosa, B. subtilis, $S$. aureus, E. coli and Streptococcus sp.) by evaluation of the inhibition of zones. Generally, all S. maxima extracts were found to be effective with antibacterial activity and were dose dependent. This phenomenon was in agreement with that found in this study. The most susceptible bacteria were Streptococcus sp. and B. subtilis to S. maxima with highest inhibition zones ranged 6-13 $\mathrm{mm}$ at concentrations of $100-400 \mu \mathrm{l} / \mathrm{disk}$. It is of interest to note that all $S$. maxima extracts manifested similar degrees of susceptible towards both Gram-positive and Gram-negative bacteria. The lower inhibition zone ranged from 6 to $9 \mathrm{~mm}$ of extracts obtained for S. maxima.

\section{CONCLUSION}

The present work describes an efficient method for extraction and antibacterial activity of phycocyanin obtained from Oscillatoria sp. The partially purified extracts of phycocyanins could inhibit some Bacterial pathogens. The efficacy of phycocyanin on cancer therapy and antimicrobial activity against other bacterial pathogens will be tested in future. Phycocyanin is a natural blue pigmented protein is a water soluble and highly fluorescent. It is effectively active against human pathogens such as Klebsiella sp., Pseudomonas sp., and Staphylococcus aureus.

\section{Financial support and sponsorship: Nil.}

Conflict of Interests: There are no conflicts of interest.

\section{REFERENCES}

Bennett A, Bogorad L. Complementary chromatic adaptation in a filamentous blue-green alga. Journal of Cell Biology,1973; 58:419-435.

Bogorad L. Phycobiliproteins and complementary chromatic adaptation. Annual Review of Plant Physiology, 1975; 26: 369-401.

Callegari JP. Feu Vert Pour Les Microalgues. Biofuture, 1989; 76:25-40.

De Pauw N, G Persoone. Micro-algae for aquaculture, Microalgal biotechnology. Cambridge University press, Cambridge United Kingdom.P, 1992; 197-221.

Iijima N, Shimamatsu H. (inventors; Dainippon Ink and Chemicals assignee). Antitumor agent and method of treatment therewith, US Patent pending. ref p1150-726-A82679, App.15
Johnson EA. Astaxanthin from microbial sources. Critical Review of Biotechnological, 1991; 11: 297-326.

Lowry HO, Rosenbrough NJ, Farr AL, Randall RJ. Protein measurement with the Folin phenol reagent. Journal of Biological Chemistry, 1991; 193: 265-275.

Metting B, Borowitzka MA, Borowitzka LJ. Micro-algae in agriculture, Micro-algal biotechnology. Cambridge University press, Cambridge United Kingdom, 1992; 288-304.

Oswald WJ, Borowitzka MA, Borowitzka LJ. Micro-algae and waste-water treatment In Micro-algal biotechnology. Cambridge University press, Cambridge United Kingdom, 1992; 305-328.

Razzak SA, Hossain MM, Lucky RA, Bassi AS, de Lasa H. Integrated $\mathrm{CO} 2$ capture, wastewater treatment and biofuel production by microalgae culturing - a review. Renewable Sustainable Energy Rev., 2013; 27: 622-653.

Rippka R, Deruelles J, Waterbury J, Herdman M, Stanier RY. Generic assignments, strain histories and properties of pure cultures of cyanobacteria. Journal of General Microbiology, 1979, 111:1-61.

Sarada R, Pillai MG, Ravishankar GA. Phycocyanin from Spirulina sp: influence of processing of biomass on phycocyanin yield, analysis of efficacy of extraction methods and stability studies on phycocyanin. Process Biochemical,1999; 34: 795-801.

Silveira ST, Burkert JFM, Costa JAV, Burkert CAV, Kalil SJ. Optimization of phycocyanin extraction from Spirulina platensis using factorial design. Bioresources. Technology, 2007; 98: 1629-1634.

Soni B, Kalavadia B, Trivedi U, Madamwar D. Extraction, purification and characterization of phycocyanin from Osillatoria quadripunctulata-isolated from the rocky shores of Bet-Dwarka, Gujarat, India. Process Biochemical, 2006; 41: 2017-2023.

Telford WG, Moss MW, Morseman JP, Allnutt TFC. Cyanobacterial stabilized phycobilisomes as fluorochromes for extracellular antigen detection by flow cytometry. Journal of Immunology. Methods,2011; 254:13-30.

Viskari PJ, Colyer CC. Rapid extraction of phycobiliproteins from cultured cyanobacteria samples. Analytical Biochemistry, 2003; 319: $263-271$.

Yamanaka G and Glazer AN. Dynamic aspects of phycobilisome structure. Archives of Microbiology, 1980; 124: 39-47.

Zhu L, Wang Z, Shu Q, Takala J, Hiltunen E, Feng P, Yuan Z. Nutrient removal and biodiesel production by integration of freshwater algae cultivation with piggery wastewater treatment. Water Res., 2013; 47: 4294-4302.

\section{How to cite this article:}

Shanmugam A, Sigamani S, Venkatachalam H, Jayaraman J, Ramamurthy D. Antibacterial activity of extracted phycocyanin from Oscillatoria sp. J App Pharm Sci, 2017; 7 (03): 062-067. 